\title{
Erratum to: Pharmacoeconomic effect of compliance with pharmacist's intervention based on cancer chemotherapy regimens: a cohort study
}

Makoto Hayashi ${ }^{1,2^{*}}$, Akimasa Yamatani ${ }^{1}$, Hiromu Funaki ${ }^{1}$ and Kenichi Miyamoto ${ }^{2}$

Unfortunately, the original version of this article [1] contained two errors. The symbol "Equal contributors" was incorrectly attributed to all authors and the email address from the corresponding author was also included incorrectly. The symbol "Equal contributors" has been removed and the correct email address of the corresponding author can be found in this erratum.

Received: 18 January 2016 Accepted: 18 January 2016

Published: 26 January 2016

\section{References}

1. Hayashi M, Yamatani A, Funaki H, Miyamoto K. Pharmacoeconomic effect of compliance with pharmacist's intervention based on cancer chemotherapy regimens: a cohort study. J Pharm Health Care Sci. 2015;1:10.

\footnotetext{
* Correspondence: hayashim@nnh.hosp.go.jp

${ }^{1}$ Department of Pharmacy, National Hospital Organization Kanazawa Medical Center, 1-1 Shimoishibiki-machi, Kanazawa, Ishikawa 920-8650, Japan

${ }^{2}$ Department of Medicinal Informatics, Graduate School of Medical Science,

Kanazawa University, 13-1 Takara-machi, Kanazawa, Ishikawa 920-8641, Japan
}

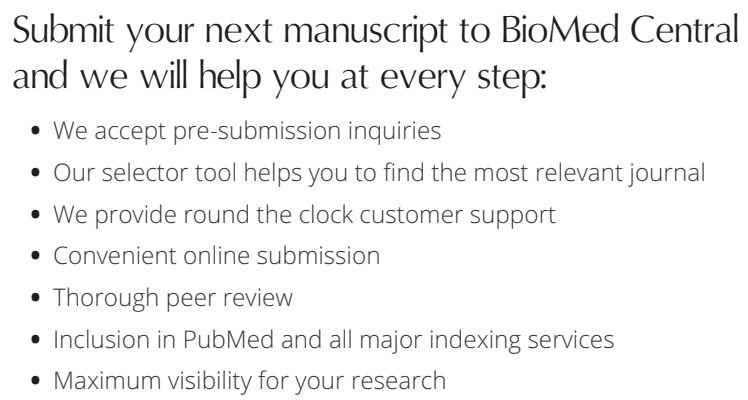

Submit your next manuscript to BioMed Central and we will help you at every step:

- We accept pre-submission inquiries

- Our selector tool helps you to find the most relevant journal

- We provide round the clock customer support

- Convenient online submission

- Thorough peer review

- Inclusion in PubMed and all major indexing services

- Maximum visibility for your research

Submit your manuscript at

www.biomedcentral.com/submit 